\title{
Cauda Equina Syndrome Due to Lumbar Disc Herniation: a Review of Literature
}

\author{
Stylianos Kapetanakis ${ }^{1}$, Constantinos Chaniotakis' ${ }^{1}$, Constantinos Kazakos ${ }^{2}$, \\ Jannis V. Papathanasiou ${ }^{3}$ \\ ${ }^{1}$ Department of Spine Surgery and Deformities, European Interbalkan Center of Thessaloniki, Greece \\ ${ }^{2}$ Department of Orthopaedic Surgery, University Hospital of Alexandroupolis, Democritus University of Thrace, Greece \\ ${ }^{3}$ Department of Medical Imaging, Allergology and Physical Medicine, Faculty of Dental Medicine, Medical University of Plovdiv, \\ Plovdiv, Bulgaria
}

\section{Correspondence: \\ Jannis V. Papathanasiou, Depart- ment of Medical Imaging, Aller- gology and Physical Medicine, Faculty of Dental Medicine, Medical University of Plovdiv, 3 Hristo Botev Blvd., 4002 Plovdiv, Bulgaria E-mail: giannipap@yahoo.co.uk Tel: +359889101178}

Received: 27 Jul 2016

Accepted: 08 March 2017

Published Online: 18 Apr 2017

Published: 22 Dec 2017

Key words: cauda equina syndrome, lumbar disc herniation, lumbar disc prolapse, low back pain, neurological disorders in the spinal cord

Citation: Kapetanakis S, Chaniotakis C, Kazakos C, Papathanasiou JV. Cauda equina syndrome due to lumbar disc herniation: a review of literature.

Folia Medica 2017;59(4);377-86. doi: 10.1515/folmed-2017-0038

\begin{abstract}
Cauda equina syndrome (CES) is a rare neurologic condition that is caused by compression of the cauda equina. Cauda equina consists of spinal nerves L2-L5, S1-S5 and the coccygeal nerve. The compression of these nerve roots can be caused mainly by lumbar disc herniation ( $45 \%$ of all causes). The diagnosis consists of two critical points: a) detailed history and physical examination and b) MRI or CT. The gold standard of the treatment of this syndrome is the surgical approach in combination with the timing of onset of symptoms. The surgery as an emergency situation is recommended in the first 48 hours of onset of symptoms. Any delay in diagnosis and treatment leads to a poor prognosis of CES.
\end{abstract}

\section{INTRODUCTION}

The spinal cord is the continuation of the medulla oblongata, which ends at the medullary cone. A bundle of spinal nerves and spinal nerve roots begins from the medullary cone and forms the cauda equina. Specifically, the cauda equina consists of the second through fifth lumbar nerve pairs, all of the five sacral nerve pairs and the coccygeal nerve. ${ }^{1-3}$

One of the most common disorders of the cauda equina is presented as CES. Cauda equina syndrome is a rare and serious neurological disease due to the pressure of the cauda equina. ${ }^{1,4-7}$ The pressure causes sensory and mobility problems in humans. The main cause of CES is the lumbar disk herniation (LDH). CES due to LDH is $1-3 \%$ of all disc herniations. ${ }^{8-17}$ There are also other causes that lead to CES such as an accident that injured the spine, complications with spinal anesthesia, drug side effects and vascular lesions of the spinal cord. 5,9,18,19 Patients usually present symptoms such as low back pain with unilateral or bilateral sciatica, reduced sensation in the saddle area, reduction of sexual function, fecal incontinence, bladder dysfunction, muscular weakness in legs and sensory loss in the perineum, buttocks and upper posterior thighs. ${ }^{1,6,8,19-23}$ The primary goal for the most accurate prognosis is early diagnosis of the symptoms of CES and urgent surgical decompression. 
The symptoms can occur gradually (such as the muscular weakness and frequent incidents of epilepsy) or abruptly (such as bladder disorders). According to the literature, if symptoms are presented abruptly, there must be a surgery within the next 48 hours. ${ }^{6-8,12,18,24-27}$ After that period, the number of permanent dysfunctions increases drastically. However, even if a surgery occurs during that period, there still could be some irreversible outcomes.

The objective of this study was to review literature about cauda equina syndrome due to lumbar disc herniation (diagnosis, effects, treatment and incidence of disease).

\section{MATERIALS AND METHODS}

A research of the literature for cauda equina syndrome was made in the School of Medicine in the Democritus University of Thrace in collaboration with the Department of Kinesitherapy Faculty of Public Health, Medical University of Sofia, Bulgaria. For this review, we performed database search of several websites such as PubMed, Google Scholar, and Scopus. While searching in the databases, key words such as cauda equina, cauda equina syndrome, lumbar disc herniation, low back pain and neurological disorders in the spinal cord were used. Each keyword was used alone or in combination with the others so that the variety of the results in the research would broaden. This research includes articles that are published in English, French or German and indicate the symptomatology, etiologies, clinical approach and the treatment of CES. In addition to this, statistic surveys and clinical cases are included in order to understand the frequency of the syndrome.

\section{ANATOMY OF THE CAUDA EQUINA}

THE POSITION OF THE CAUDA EQUINA

The spinal cord extends from the medulla oblongata to the level of T12-L1. The next part of the spinal cord is called medullary cone. The cauda equina begins from the medullary cone and consists of the spinal nerves L2-L5, S1-S5 and the coccygeal nerve. . $^{3,21,22,28,30}$ These nerves are composed of sensory (posterior) and motor (anterior) nerve roots and their functions include the sensory innervation to the saddle area, the voluntary control of the outer surface of the rectum and the urinary sphincters and the sensory and motor innervation of the lower limbs. Any disturbance in the area of the cauda equina affects the aforementioned operations. The cauda equina is located in an enclosed cavity, which is called thecal sac and is filled with cerebrospinal fluid in the subarachnoid space. ${ }^{1-3,7,29}$

EMBRYOLOGICAL DEVELOPMENT OF THE CAUDA EQUINA

The cauda equina in the human embryo starts developing at the beginning of the third month, when its spinal cord extends the whole length of its body. After the first three months, a disproportion in the rate of growth of the bones and the cartilages of the vertebral column, and the spinal cord is observed. The first two grow faster than the spinal cord. This phenomenon causes the nerves that are located below the superior cervical region to follow a slanted path. Therefore, the lumbar and sacral nerves move downward and vertically inside the spinal canal, before exiting the intervertebral foramina. The nerve roots that are created below the $\mathrm{L} 1$ form the cauda equina. ${ }^{7,31,32}$

TOPOGRAPHY OF THE NERVE ROOTS OF THE CAUDA EQUINA There are two methods that visualize with great clarity the nerve roots of the cauda equina. They are called contrast-enhanced CT and surface-coil MRI. These methods are effective for the understanding of the distribution of nerve roots at each disc level within the thecal sac. Especially, at L5-S1 intervertebral level, the S1 root is located anterior and lateral. At intervertebral level of L4-L5, the L5 root is placed anterolateral and it changes the location of the S1 root. The sacral roots are lying in the posterior portion. The motor roots are situated anterior and medial and the sensory roots are situated posterior and lateral. At L3-L4 intervertebral level, an increased concentration of roots is observed because the L4 roots appear in the anterior portion and the other roots (L5-S5) are moved dorsally. Finally, at intervertebral level of L2-L3, the thecal sac consists mostly of roots, with the motor roots being located anterior in regards to the sensory ones. ${ }^{1,2,7,29}$

The anterior and posterior roots include five individual strands. At the level of the S1, the largest anterior and posterior roots are found. Those roots can also be located from L3 to S2. The roots exit lateral to the thecal sac at an angle of approximately 40 degrees at the level of L1-L5. However, this angle is reduced to $22 \pm 4$ degrees at the $\mathrm{S} 1$ root. The nerve roots of the cauda equina have a connective tissue which is not dense. As a result, an absence of diffusion is detected (Fig. 1). ${ }^{1,7}$ 

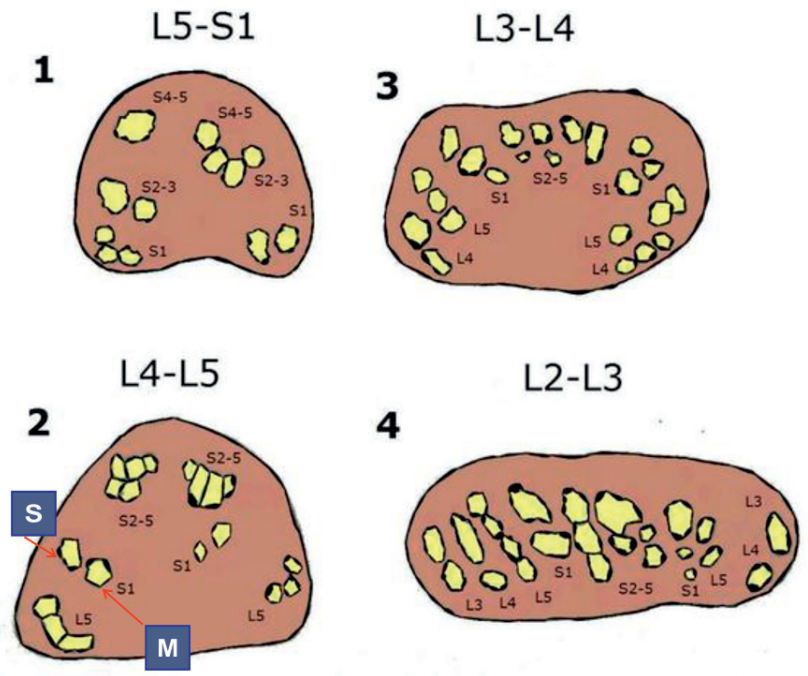

Figure 1. Diagrams of the cauda equina on CT and MRI. ( $\mathrm{M}=$ motor, $\mathrm{S}=$ sensory $)$.

\section{VASCULAR ANATOMY OF THE CAUDA EQUINA}

In general, the vascular supply of the spinal cord originates from the anterior spinal artery and the other two posterior spinal arteries. The circulation on the major part depends on the anterior and posterior radicular and partial arteries, which are located beside the spinal nerves. These arteries originate from the cervical, spinal, posterior intercostal and lumbar arteries. , $^{1,29}$

The vascular supply of the cauda equina is associated with the arteries, which accompany the anterior and posterior nerve roots of the cauda equina. Every nerve has near it at least one small artery. The crucial part of the blood circulation of the cauda equina consists of the radicular arteries because they surround the nerve roots. ${ }^{7,29}$ Any compression or occlusion on the radicular arteries can cause problems in the vascular supply of the cauda equina (for example ischemia of the portion of the nerve root). The ilio-lumbar artery drains to the fifth lumbar artery, which originates from the iliac artery as well as the aorta. The arteries that follow the sacral nerve roots and nerves arise from the branches of the hypogastric artery, the medial sacral artery or directly from the hypogastric artery. It is also remarkable that most of the arteries of the cauda equina are 'end' arteries, because they do not have anastomotic branches. ${ }^{7}$

THE DURAL SAC AND THE COMPRESSION OF THE CAUDA EQUINA

In the lumbar spine, the relation between the dimensions of the dural sac and the compression of the cauda equina constitutes an important detail that should be mentioned. ${ }^{29}$ According to various searches, the minimal space that is occupied by the dural sac and is necessary for the nerve roots of the cauda equina is about $77 \pm 13 \mathrm{~mm}^{2}$ at the level of L3. This number constitutes almost $44 \%$ of the normal cross sectional area. Any reduction of this area causes an increase in the intrathecal pressure of the cerebrospinal fluid between the nerve roots of the cauda equina. Especially, the pressure inside the dural sac of the cauda equina elevates when the cross sectional area ranges between 60 and 80 $\mathrm{mm}^{2}$. As a result, if the cross sectional area of the dural sac decreases to $63 \pm 13 \mathrm{~mm}^{2}$, the pressure is increased to $50 \mathrm{mmHg}$. In addition to this, if the cross sectional area of the dural sac is reduced to $57 \pm 11 \mathrm{~mm}^{2}$, the pressure increases to $100 \mathrm{mmHg}$. Therefore, a small reduction can cause an abrupt increase in the pressure inside the dural sac. ${ }^{6,7}$

\section{SYMPTOMATOLOGY OF CES DUE TO LUMBAR DISC HERNIATION}

In CES, the main causes that result to the patient's reduction of the sensory and the motor expression of the lumbosacral nerves, present symptoms such as low back pain, unilateral or bilateral sciatica, saddle anesthesia, muscular weakness in legs, disturbances of bladder, loss of the tone in the anal sphincter and decreased sexual function. 4,6,8,10,16,19,27,30,33-35 CES affects the reflexes as bulbocavernosus, medioplantar and Achilles tendon. 5,9,24,25

\section{LOW BACK PAIN}

More and more people begin to experience low back pain each day. This medical condition is related to the pain in the lumbar spine. Seventy to eighty percent of individuals experience an episode of this pain during their lifetime. ${ }^{22,24,36}$ Low back pain is caused by the degeneration of the lower lumbar spaces. This degeneration starts from the creation of a lumbar disc herniation. ${ }^{10,36}$ There are three types of low back pain: the acute, subacute and chronic. ${ }^{7}$ Due to the fact that low back pain is directly related to CES, the patients should not ignore the sensation of the pain, while the clinical doctor suspects it for the possibility of the existence of the syndrome.

The methods that are used for the diagnosis of low back pain are the MRI and the CT. The MRI displays all of the several causes of low back pain, while the CT method portrays the same causes but it mainly concerns the patients who may not 
undergo in a magnetic tomography. ${ }^{7,10,36}$

\section{SCIATICA}

This condition is caused by any damage in the sciatic nerve. This nerve originates from the primary branches of the sacral plexus (L4-S3). The mainly reason of sciatica is the lumbar disc herniation, which reduces the sensation and the movability of the legs and the buttocks. The sciatica can either be unilateral or bilateral. ${ }^{14,24,25,34}$ The pain of the sciatica extends from the lower back to the legs. At the level of L5-S1, the damages of these nerve roots constitute the most frequent case of sciatica. There are two types of sciatica, the peripheral and the proximal sciatica. The first one is referred to lesions in the spinal cord due to lumbar disc herniation. The second one is referred to the pressure outside of the spinal cord (i.e. the pressure inside of the pelvis, the buttocks and the femur (Table 1). ${ }^{7,18}$

Table 1. Symptomatology and frequency ${ }^{1,24}$

\begin{tabular}{lc}
\hline \multicolumn{1}{c}{ Symptoms } & $\begin{array}{c}\text { Frequency, } \\
\text { \% }\end{array}$ \\
\hline Low back pain & 83 \\
Micturition dysfunction & 88 \\
Dysfunction of defecation & 47 \\
Saddle anesthesia & 81 \\
Unilateral or bilateral sciatica & 95.50 \\
Erectile dysfunction & 5 \\
\hline
\end{tabular}

\section{PATHOPHYSIOLOGY OF CES}

There are many causes that lead to CES. The most common cause is lumbar disc herniation (LDH) (Fig. 2). ${ }^{4,18,19,25}$ The intervertebral disc is located between two vertebrae. This disc is composed of the annulus fibrosus, which is situated on the outside, and the nucleus pulposus, which is situated on the inside. ${ }^{20,29} \mathrm{LDH}$ is created when an area of the annulus fibrosus is destroyed and the nucleus pulposus is directed through the annulus fibrosus to the spinal canal (Fig. 3). In the spinal canal, the nucleus pulposus causes the pressure of the nerves. ${ }^{2,20}$ The most common levels for the creation of an LDH are L4-L5 and L5-S1. ${ }^{20,29,30,34,37}$ Furthermore, the degenerative causes are spondylolisthesis and lumbar spinal stenosis. Other causes are also quite important as a penetrating injury, which is caused by an accident (for example by a vehicle), a blunt trauma, which is caused by a gunshot or a sharp object, spinal or epidural anesthesia, vascular lesions of the spinal cord (such as thrombus formation or epidural/subdural hematoma), bacterial abscess, tuberculosis, schistosomiasis, arthritis (Bechterew's disease), osteoporotic collapse, rheumatoid arthritis and ankylosing spondylitis. There are other causes of CES that are characterized as neoplastic. These are ependymoma, neurofibroma, meningioma, schwannoma, lymphoma, and metastases of cancer (Table 2). $1,5,7,9,18,29,38$

\section{EPIDEMIOLOGY OF CES}

Generally, CES is a disease of low incidence in humans and appears in 1 case per 33,000 to 1 case per $100,000 .{ }^{11,29,30}$ CES due to lumbar disc herniation composes $1-3 \%$ of all herniated lumbar discs. ${ }^{9-14,16,17,27,36}$ Concerning the literature, $45 \%$ of the cases of CES are caused by lumbar disc herniation. Moreover, $2-6 \%$ of lumbar disc operations

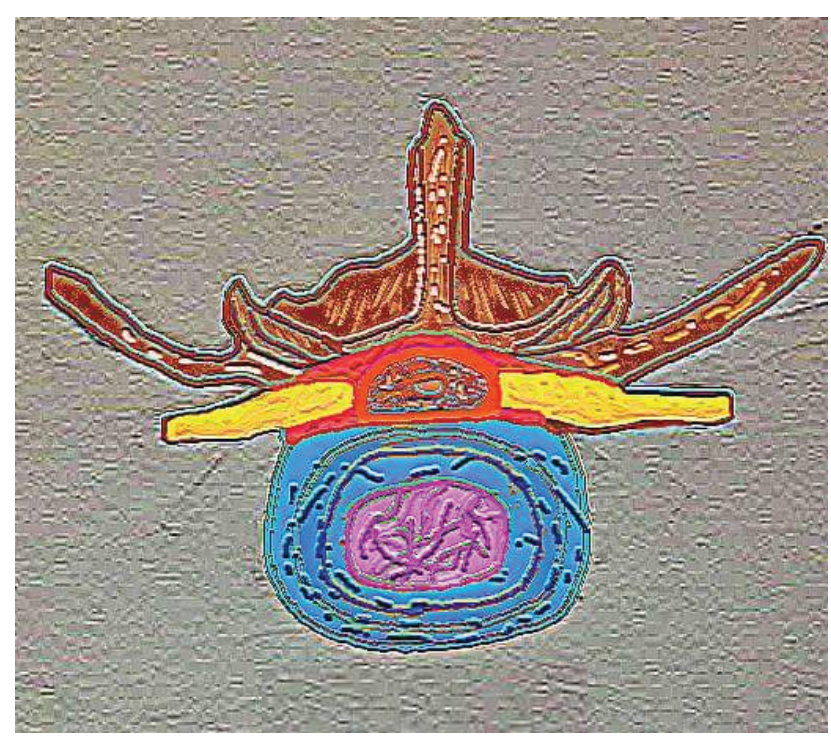

Figure 2. Normal disc.

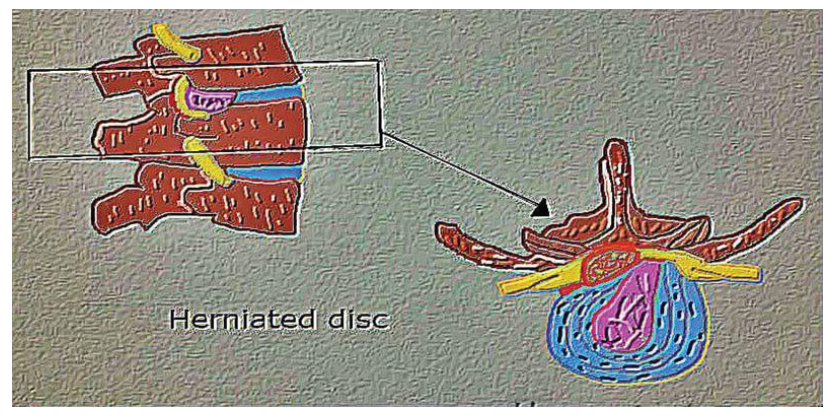

Figure 3. Lumbar disc herniation. 
Table 2. Causes and frequency ${ }^{4,9}$

\begin{tabular}{lc}
\hline \multicolumn{2}{c}{ Most common causes of CES } \\
\hline Cause & $\begin{array}{c}\text { Frequency } \\
\text { (\%) }\end{array}$ \\
\hline Lumbar disc herniation & 45 \\
Tumor & 29 \\
Infection & 28 \\
Stenosis & 21 \\
Hematoma & 20 \\
Inflammatory & 12 \\
Vascular & 11 \\
\hline
\end{tabular}

cause CES. Patients that have had a surgery because of HNP are predisposed to CES (incidence 1-10\%). ${ }^{4}$ The incidence of many of the symptoms is: saddle anesthesia $-80 \%$, low back pain - $70-80 \%$, sciatica - 95\%, and micturition dysfunction - 88\%. ${ }^{1,24}$ Even though sphincter paralysis appears in an incidence of $2 \%$, it is a destructive complication of the prolapse of the lumbar intervertebral disc. ${ }^{16,24}$

\section{CLINICAL APPROACH}

\section{The Classification of CES}

The classification includes the incomplete CES (CESI) and the complete CES (CES-R). According to the first case, patients present with urinary difficulties, limited urinary sensation and loss of ability to void. This shows that these patients do not present a complete dysfunction of the bladder. Motor sensation is reduced with bilateral sciatica, lower extremity weakness and saddle anesthesia. 6,25,29,39 For the urination, the patients use the abdominal compression (neurogenic origin). ${ }^{18}$ According to the second case, patients present a complete urinary retention. CES-R is characterized by overflow incontinence, absence control of the bladder and complete deficit of saddle anesthesia. ${ }^{1,6,18}$ The clinical doctor must pay attention to this classification of CES, because CES-I can evolve in CES-R. CES-I is presented in $30-50 \%$ and CES-R is presented in $50-70 \% .{ }^{18}$ The outcome of CES-I is generally favorable if there is an urgent surgical decompression within 48 hours. CES-R has unsatisfying prognosis, regardless the timetable of the surgical technique. $7,25,40$

The diagnosis of CES-diagnostic tools

The diagnosis requires a detailed history and a physical examination. The gold standard, during the diagnosis, is composed of many points as the duration of the symptoms, the nature of the complaints, sexual and bladder dysfunction (urinary retention), the mechanism of injury, the medication and surgical history. Regarding the physical examination, the doctor examines the perineal sensation and sphincter (the retention of feces), the muscular weakness, the saddle anesthesia and the existence of low back pain and sciatica. In addition, the doctor examines the function of the bladder palpating the suprapubic region. The urodynamic testing leads to an early diagnosis of CES. $1,7,9,25,34$

There are two reflexes which should be examined, the anal wink (a superficial reflex) and the bulbocavernosus reflex. ${ }^{5,24,25,33}$ In the first reflex, the stimulation of the tone of the sphincter and the perirectal area is checked. This examination leads to the involuntary contraction of the anus. ${ }^{25,35}$ The second reflex is elicited by an applied pressure in the glans of the penis or the clitoris or via traction on a Foley catheter, so the retraction of the anus is caused as a physiological reaction. $1,7,9,18,25,34$

The methods that help to identify the reasons of CES are the MRI and the CT. Generally, the MRI is performed to prove any compression of the thecal sac. ${ }^{19,24,25,30,41}$ The MRI is the first clinical examination in the spinal cord for the patients who present the symptoms of CES..$^{5,15,18,20,42,43}$ Lumbar disc herniation, tumor, hematoma and infection are illustrated in the MRI. In the infection or in the neoplastic etiology of CES, the administration of intravenous contrast offers more detail in the imaging. But this method has many disadvantages. Claustrophobic patients cannot be inside a tube for a long time. Also, the MRI should be avoided in some cases as the presence of pacemakers, aneurysm clips and metal fragments in the eyes or near vital structures. The CT myelography is an invasive procedure, which is used when the MRI

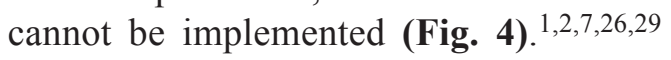

\section{Pharmacology and treatment of CES}

There are three methods which lead to the treatment of CES. The first method is related to surgical methods. It aims the decompression of the cauda equina and it is accomplished by laminectomy or discectomy. The treatment of CES with the above method requires an urgent surgery, within 24-48 hours from the time of the appearance of the symptoms. ${ }^{1,3,6,12,16-18,25,28,44,45}$ In contrast to this, there are two cases of CES, which should not be treated by surgery. These are the chronic innate 


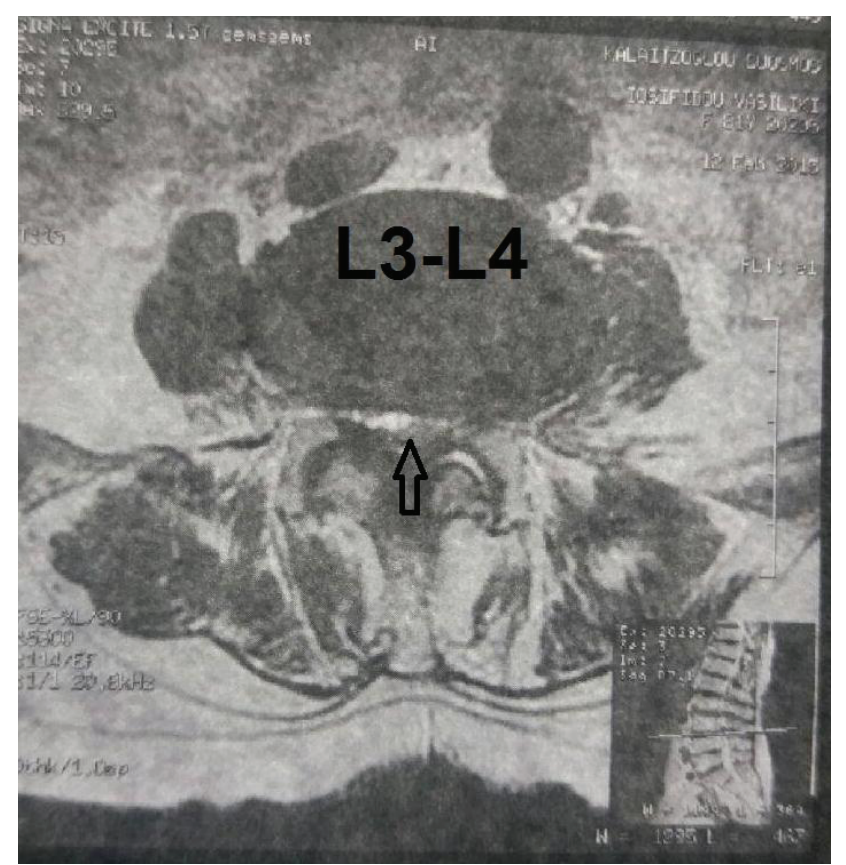

Figure 4. Epidural syndrome in patient with L3-L4 central spinal stenosis.

arachnoiditis and CES due to chronic ankylosing spondylitis. ${ }^{1,7,11,25,26,45}$

The other two methods are related to the pharmaceutical therapy. For the first pharmaceutical method, anti-inflammatory drugs are administered, while for the second one the use of vasodilator drugs is broad. The vasodilatory agent is a bolus treatment with lipoprostaglandin E1, which aims to the systematic relief of lower limbs pain and numbness. Experimental studies in dogs mention that the intravenous treatment with OP- 1206 (prostaglandin E1 derivative) improves the nerve conduction velocity. In rats, the same union, led to the increase of the local flow of the spinal cord. This method has efficacy only in patients with moderate narrowing, which is related in neurogenic claudication. In an urgent situation, the pharmaceutical therapy does not offer any results. Drugs with the same action are the adenosine or the adenosine kinase inhibitors (A2 adenosine receptor). The last method is the administration of steroids. Steroids are administered epidurally or intrathecally with the combination of local anesthetics., ${ }^{2,7}$

The Role of Physical and Rehabilitation Medicine (PRM) in Cauda Equina Syndrome

CES seems to be a potential complication of PRM interventions. Patients, who were diagnosed with low back pain or lumbar disc herniation, developed CES due to spinal manipulation. Especially, a simple radiculopathy could lead to bowel and bladder dysfunction due to the compression of the nerves as a complication of PRM treatment. ${ }^{5}$ Physicians should be able to diagnose CES and refer the patients to PRM specialists to cure the damage and start the treatment of syndrome without delays. CES should be treated with surgery performed by spinal surgeons, because it belongs to a category of the most serious diseases of spinal cord known as "red flags". Therefore, CES is an absolute indication for urgent surgery. ${ }^{40,46}$

\section{SURGICAL METHOD AND TIMING OF DECOMPRESSION}

The surgical technique is the most common method for the treatment of CES. 3,5,8,14,19,28,41 According to the literature, a wide laminectomy and the extensive decompression of the nerves of CES is one of the methods which are the "key role" in the treatment of CES. ${ }^{1,8,12,25,27,29,45}$ Several authors report that a removing of the disc space material "takes place" after the decompression. In the case where a hematoma or abscesses exist, the clinical doctor performs a thorough evacuation. Another surgical technique is the discectomy or the combination of laminectomy and discectomy. 1,5,12,25,41 The laminotomy/ hemilaminectomy with micro-discectomy, is a technique which is not recommended because of retraction of the thecal sac, which leads to aggravated damages of nerves during the decompression. In few instances, the clinical doctor uses the transthecal decompression. . $7,9,25,27$ During the last years, a new method was created in order to minimize the damages of normal tissues. It is a minimal invasive surgery under local anesthesia, known as endoscopic and provides huge expectancies for the treatment of CES. ${ }^{14}$

Generally, CES due to LDH is an urgent surgical situation. The timing of surgical technique is related to the prognosis of CES. 2,6,12,17,18,23,25,44 If the symptoms appear in a dramatic rhythm, the surgical technique should be performed within the next 48 hours. ${ }^{9,22,24,26,27,45}$ After that period, the chances for permanent damage to the bladder, the intestine and the ambulation increase. In addition to this, the sexual impotence and the permanent pain are presented after 48 hours. Especially, there is a better prognosis for the bladder dysfunction within 48 hours than after that period. $4,38,39,45$

\section{Prognosis}

The prognosis presents important and critical information regarding the progress of each disease. Concerning the literature, the prognosis of the acute 
CES is generally considered favorable within 48 hours. ${ }^{12,17,23,26,44} 70 \%$ of the patients who are submitted in a surgery of discectomy, present a complete recovery of the bladder'sfunction. ${ }^{9,13,18,21,38,39}$ Postoperative improvements, after an ablation of the lumbar disc herniation, are the following: $83 \%$ pain relief, $75 \%$ motor function, $73 \%$ urinary continence, $67 \%$ sexual function, $64 \%$ rectal function and $56 \%$ sensory restoration. ${ }^{25}$ Patients of CES-I have an improvement prognosis in relation to the patients of CES with urinary retention. ${ }^{14,18,25,29,39}$ If the patient experiences leg pain, it is considered to be an unfavorable sign. The bilateral sciatica has worse results than the unilateral sciatica. $2,6,9,18,25,34,38$

The history of the patient affects largely the prognosis of CES. Patients that have a surgical history of chronic low back pain present a poor outcome in the urination and the bowel. ${ }^{13,25,26,29}$ Especially, patients who present this specific symptom develop a hazard of maintaining urinary incontinence and poor recovery of the anal function 11 and 25 times respectively, more than those who do not experience this situation. Furthermore, the history of anal dysfunction leads to 10 times more sensory deficits. Older people present a poor prognosis of the sexual function. Men show reduced sensitivity to the penis and dysfunction of the erection, while women present reduced sensitivity and urinary incontinence during the intercourse. ${ }^{8,25}$ Each patient presents a different level of pain and/ or residual neurological deficits. According to a survey, 20\% of patients require a continued support with the catheterization and the colostomy. ${ }^{18}$ Also, patients need support from their family because they might develop psychological problems as anxiety and depression. . $^{18,25,38}$

\section{MEDICOLEGAL CONSIDERATIONS}

Medicolegal is a critical point of CES because it is related to its diagnosis and treatment. ${ }^{37,47}$ The reasons that lead to Medicolegal, are: 1) failure of the clinical doctor to identify the syndrome, 2) inadequate physical examination of the neurosurgeon, orthopedic or another specialist clinical doctor (indifference to any symptoms), 3) failure of communication between the staff, 4) deficiency of an emergency room physician in order to recognize CES, 5) deficiency of diagnostic methods, as MRI, $\mathrm{CT}$, and specialist spinal surgical facilities, 6) delay of the surgery, 7) failure of physical examination of the patient in a timely manner and 8) inadequate postoperative examination. ${ }^{18,37}$ As mentioned, the surgical decompression of CES within 24 to 48 hours leads to an advantageous prognosis. However, many lesions remain for a long time. In that case, the relatives of the patient believe that the clinical doctor has failed the surgery, although he/she has faced CES appropriately. ${ }^{18,48}$ As a result, medicolical does not impose compensation to the clinical doctor.

\section{DISCUSSION}

The clinical picture of CES presents symptoms such as low back pain, sciatica (unilateral or bilateral), saddle anesthesia, muscular weakness in legs, bladder dysfunction, decreased sexual function and loss of the tone in the anal sphincter. $4,8,16,33,35$ These symptoms appear in several frequencies. The focus should be on the urinary retention because it provides the classification of CES which is CES-R (a complete urinary retention) and CES-I (an incomplete urinary retention). ${ }^{6,18,25}$ The symptomatology of CES is characteristic. If the clinical doctor is aware of CES, he/she can lead to the correct diagnosis. In the diagnosis, the gold standard is a detailed history and a physical examination. The main cause that leads to CES is lumbar disc herniation. ${ }^{4,9}$ There are two methods that help to identify the LDH. These methods are the MRI and the CT. ${ }^{19,24,41}$ The MRI depicts detailed pictures of spine. The CT is used when there are obstacles to the implementation of MRI, such as claustrophobic patients. ${ }^{1,2,26}$

Concerning the treatment of CES, the most common method is the surgical approach. According to several authors these methods are:

a) The wide laminectomy and the extensive decompression of the nerves of CES. . $^{1,8,12,29}$

b) removing of the disc space material, after the decompression,

c) the discectomy or the combination of laminectomy and discectomy ${ }^{1,5,25,41}$ and

d) the endoscopic, a minimal invasive surgery under local anesthesia. ${ }^{14}$

These methods are used for the surgical treatment of CES due to lumbar disc herniation. After the decompression, if there is a traumatic or an iatrogenic instability, the surgical approach is a lumbar interbody fusion..$^{25,49}$ The gold standard of the surgical technique is the timing of onset of symptoms. The surgical treatment leads to a favorable prognosis, if the surgery is performed within 24-48 hours of onset of symptoms. . $2,23,26,44^{2}$

The aim of this review is the analysis of a rare neurological syndrome - cauda equina syndrome due to lumbar disc herniation. This project contains 
the following topics: anatomy of the cauda equina, symptomatology, pathophysiology, epidemiology, clinical approach and medicolegal. The clinical doctor has to acknowledge the following three parameters in order to be able to make a favorable prognosis: surgical techniques, the treatment of the syndrome from the onset of symptoms and medicolegal.

\section{CONCLUSION}

CES due to LDH is a crucial situation. Patients and doctors need to be informed because it is a rare neurological syndrome. Nevertheless, with the use of the appropriate treatment, complications can be greatly reduced. The timing of the onset of symptoms constitutes a critical point for the diagnosis, treatment and the prognosis of CES. The medical doctor considers the patient's history and his/her physical examination as his first points in order to diagnose CES. The complete diagnosis is developed in combination with the examination of MRI and CT. The diagnosis determines the timing of the treatment. The desired timing of the decompression of the cauda equina is between 24 and 48 hours. During this time, complications are reduced or disappeared completely. After 48 hours, complications increase dramatically and the damages are permanent. The prognosis of CES depends on the timing of the decompression. We encourage all the scientists to investigate more about this disease.

\section{REFERENCES}

1. Gitelman A, Hishmeh S, Morelli BN, et al. Cauda equina syndrome: a comprehensive review. Am J Orthop (Belle Mead NJ) 2008;37(11):556-62.

2. Harrop JS, Hunt GE Jr, Vaccaro AR. Conus medullaris and cauda equina syndrome as a result of traumatic injuries: management principles. Neurosurg Focus 2004;16(6):e4.

3. Kim TW, Yoon JW, Heo W, et al. Lumbar disc herniation presenting cauda equina syndrome. J Korean Neurosurg Soc 2006;39(1):40-5.

4. Korse NS, Jacobs WC, Elzevier HW, et al. Complaints of micturition, defecation and sexual function in cauda equina syndrome due to lumbar disk herniation: a systematic review. Eur Spine J 2013;22(5):1019-29.

5. Tamburelli FC, Gentitiempo M, Logroscino CA. Cauda equina syndrome and spine manipulation: case report and review of the literature. Eur Spine J 2011;20(1):S128-31.

6. Chan Am, Xu LL, Pelzer NR, et al. Timing of surgical intervention in cauda equina syndrome: a systematic critical review. World Neurosurg 2014;81(3-4):640-50.

7. Orendacova J, Cizkova D, Kafka J, et al. Cauda equina syndrome. Proq Neurobiol 2001;64(6):613-37.

8. Tamburelli FC, Genitiempo M, Bochicchio M, et al. Cauda equina syndrome: evaluation of the clinical outcome. Eur Rev Med Pharnacol Sci 2014;18(7):1098-105.

9. Fraser S, Roberts L, Murphy E. Cauda equina syndrome: a literature review of its definition and clinical presentation. Arch Phys Med Rehabil 2009;90(11):1964-8.

10. Kinkade S. Evaluation and treatment of acute low back pain. Am Fam Physician 2007;75(8):1181-8.

11. Oliphant D. Safety of spinal manipulation in the treatment of lumbar disk herniations: a systematic review and risk assessment. J Manipulative Physiol Ther 2004;27(3):197-210.

12. Shapiro S. Medical realities of cauda equina syndrome secondary to lumbar disc herniation. Spine (Phila Pa 1976) 2000;25(3):348-51; discussion 352.

13. Bednar DA. Cauda equina syndrome from lumbar disc herniation. CMAJ 2016;188(4):284.

14. Li X, Dou Q, Hu S, et al. Treatment of cauda equina syndrome caused by lumbar disc herniation with percutaneous endoscopic lumbar discectomy. Acta Neurol Belg 2016;116(2):185-90.

15. Busse JW, Bhandari M, Schnittker JB, et al. Delayed presentation of cauda equina syndrome secondary to lumbar disc herniation: functional outcomes and health-related quality of life. CJEM 2001;3(4):285-91.

16. O'Laoire SA, Crockard HA, Thomas DG. Prognosis for sphincter recovery after operation for cauda equina compression owing to lumbar disc prolapse. Br Med J (Clin Res Ed) 1981;282(6279):1852-4.

17. Kohless SS, Kohles DA, Karp AP, et al. Time-dependent surgical outcomes following cauda equina syndrome diagnosis: comments on a meta-analysis. Spine (Phila Pa 1976) 2004;29(11):1281-7.

18. Cardner A, Gardner E, Morley T. Cauda equina syndrome: a review of the current clinical and medicolegal position. Eur Spine J 2011;20(5):690-7.

19. Ma B, Wu H, Jia LS, et al. Cauda equina syndrome: a review of clinical progress. Chin Med J (Engl) 2009;122(10):1214-22.

20.Humphreys SC, Eck JC. Clinical evaluation and treatment options for herniated lumbar disc. Am Fan Physician 1999;59(3):575-82, 587-8.

21. Shephard RH. Diagnosis and prognosis of cauda 
equina syndrome produced by protrusion of lumbar disk. Br Med J 1959;2(5164):1434-9.

22. Nater A, Fehlings MG. The timing of decompressive spinal surgery in cauda equina syndrome. World Neurosurg 2015;83(1):19-22.

23. Hakan T. Lumbar disk herniation presented with cauda equina syndrome in a pregnant woman. $\mathrm{J}$ Neurosci Rural Pract 2012;3(2):197-9.

24. Aly TA, Aboramadan MO. Efficacy of delayed decompression of lumbar disk herniation causing cauda equina syndrome. Orthopedics 2014;37(2):e153-156.

25. Radcliff KE, Kepler CK, Delasotta LA, et al. Current management review of thoracolumbar cord syndromes. Spine J 2011;11(9):884-92.

26. Raj D, Coleman N. Cauda equina syndrome secondary to lumbar disc herniation. Acta Orthop Beig 2008;74(4):522-7.

27. Chang HS, Nakagawa H, Mizuno J. Lumbar herniated disc presenting with cauda equina syndrome. Long-term follow-up of four cases. Surg Neurol 2000;53(2):100-4; discussion 105.

28. Fujisawa H, Igarashi S, Koyama T. Acute cauda equina syndrome secondary to lumbar disc herniation mimicking pure conus medullaris syndrome - case report. Neurol Med Chir (Tokyo) 1998;38(7):429-31.

29. McNamee J, Flynn P, O'Leary S, et al. Imaging in cauda equina syndrome - a pictorial review. Ulster Med J 2013;82(2):100-8.

30. Fuso FA, Dias AL, Letaif OB, et al. Epidemiological study of cauda equina syndrome. Acta Ortop Bras 2013;21(3):159-62.

31. Butler SJ, Bronner ME. From classical to current: Analyzing peripheral nervous system and spinal cord lineage and fate. Dev Biol 2015;398(2):135-46.

32. Griessenauer CJ, Raborn J, Foreman P, et al. Venous drainage of the spine and spinal cord: a comprehensive review of its history, embryology, anatomy, physiology and pathology. Clin Anat 2015;28(1):75-87.

33. Bruggeman AJ, Decker RC. Surgical treatment and outcomes of lumbar radiculopathy. Phys Med Rehabil Clin N Am 2011;22(1):161-77.

34. Schaeffer HR. Cauda equina compression resulting from massive lumbar disc extrusion. Aust N Z J Surg 1966;35(4):300-6.

35. Jennett WB. A study of 25 cases of compression of the cauda equina by prolapsed intervertebral discs.
J Neurol Neurosurg Psychiatry 1956;19(2):109-16. 36. Boucher P, Robidaux S. Lumbar disk herniation and cauda equina syndrome following spinal manipulative therapy: a review of six court decisious in Canada. J Forensic Leg Med 2014;22:159-69.

37. Kostuik JP. Medicolegal consequences of cauda equina syndrome: a review. Neurosurg Focus 2004;16(6):e8.

38. Scott PJ. Bladder paralysis in cauda equina syndrome lesions from disc prolapse. J Bone Joint Surg Br 1965;47:224-35.

39. Todd NV. Cauda equina syndrome: the timing of surgery probably does influence outcome. Br J Neurosurg 2005;19(4):301-6; discussion 307-8.

40. Siebert E, Pruss H, Klingebiel R, et al. Lumbar spinal stenosis: syndrome, diagnostics and treatment. Nat Rev Neurol 2009;5(7):392-403.

41. Balasubramanian K, Kalsi P, Greenough CG, et al. Reliability of clinical assessment in diagnosing cauda equina syndrome. Br J Neurosurg 2010;24(4):383-6.

42. Kim JS, Lee SH, Arbatti NJ. Dorsal extradural lumbar disk herniation causing cauda equina syndrome: a case report and review of literature. J Korean Neurosurg Soc 2010;47(3):217-20.

43. Motiei-Langroudi R, Sadeghian H, Seddighi AS. Clinical and magnetic resonance imaging factors which may predict the need for surgery in lumbar disc herniation. Asian Spine J 2014;8(4):446-52.

44. Mercier P, Hayek G, Ben Ali H, et al. [Intradural lumbar disk hernias. Apropos of 6 cases and review of the literature.] Neurochirurgie 1997;43(3):142-7 [French].

45. McLaren AC, Bailey SI. Cauda equina syndrome: a complication of lumbar discectomy. Clin Orthop Relat Res 1986;(204):143-9.

46. Ferguson F, Holdsworth L, Rafferty D. Low back pain and physiotherapy use of red flags: the evidence from Scotland. Physiotherapy 2010;96(4):282-8.

47. Qureshi A, Sell P. Cauda equina syndrome treated by surgical decompression: the influence of timing on surgical outcome. Eur Spine J 2007;16(12):2143-51.

48. Gernon T, Ahuja S, Casey AT, et al. British Association of Spine Surgeons standards of care for cauda equina syndrome. Spine J 2015;15(3 Suppl):S2-4.

49. Tender GC, Serban, D. Minimally invasive transforaminal lumbar interbody fusion: comparison of two techniques. Chirurgia (Bucur) 2014;109(6):812-21. 


\section{Cauda Equina синдром, вызванный межпозвоночной грыжей: литературный обзор}

\section{Стилианос Капетанакис ${ }^{1}$, Константинос Каниотакис ${ }^{1}$, Константинос Казакос ${ }^{2}$, Янис В. Папатанасиу ${ }^{3}$}

\footnotetext{
${ }^{1}$ Кафедра спинальной хирургии и деформаций, Европейский межбалканский медицинский центр, Салоники, Греция

2 Кафедра ортопедической хирургии, Университетская больница - Александруполис, Фракийский университет „Демокрит“, Греция

${ }^{3}$ Кафедра образной диагностики, аллергологии и физиотерапии, Факультет дентальной медицины, Медицинский университет - Пловдив, Пловдив, Болгария
}

\begin{abstract}
Адрес для корреспонденции: Янис Папатанасиу, Кафедра образной диагностики, аллергологии и физиотерапии, Факультет дентальной медицины, Медицинский университет - Пловдив, бул. „Христо Ботев" № 3, 4002, Пловдив, Болгария E-mail: giannipap@yahoo.co.uk Тел: +359889101178
\end{abstract}

Дата получения: 27 июля 2016 Дата приемки: 08 марта 2017 Дата онлайн публикации: 18 апреля 2017

Дата публикации: 22 декабря 2017

Ключевые слова: cauda equina синдром, межпозвоночная грыжа, пролапс межпозвоночного диска, боли в пояснице, неврологические нарушения спинного мозга

\section{Образец цитирования:}

Kapetanakis S, Chaniotakis C, Kazakos C, Papathanasiou JV. Cauda equina syndrome due to lumbar disc herniation: a review of literature.

Folia Medica 2017;59(4);377-86. doi: 10.1515/folmed-2017-0038
Cauda equina синдром (синдром конского хвоста) (KEC) является редко встречающимся неврологическим состоянием, причиной появления которого является сдавление cauda equine. Cauda equine состоит из спинномозговых нервов L2-L5, S1-S5 и копчикового нерва. Сдавление данных нервных корешков вызвано в основном межпозвоночной грыжей (45\% всех случаев). Диагноз обосновывается на основании двух основных факторов: а) подробного анамнеза и физикального обследования и б) ЯМР или КТ. Золотой стандарт лечения данного синдрома включает в себя хирургический подход в сочетании со временем проявления симптомов. Хирургическое вмешательство в качестве неотложной меры рекомендуется в течение первых 48 часов с момента проявления симптомов. Любое промедление с уточнением диагноза и лечением чревато плохими последствиями для КЕС. 